\title{
Konstruksi Gender Dalam Relasi Intimate Relationship Pada Novel Friendzone: Lempar Kode Sembunyi Hati Karya Alnira (Sebuah Analisis Framing)
}

\author{
Ratnawati \\ Universitas Merdeka Madiun \\ ratnaa798@gmail.com \\ Nunik Hariyani \\ Universitas Merdeka Madiun \\ hariyani_nunik@yahoo.com \\ Veny Ari Sejati \\ Universitas Merdeka Madiun \\ veny_ar@unmer-madiun.ac.id
}

\begin{abstract}
This research is titled Gender Construction in Intimate Relationship on "Friendzone: Lempar Kode Sembunyi Hati" Novel by Alnira (A Framing Analysis). The purpose of this research is to find the expression of feelings between men and women in intimate relationships through the novel characters, and discover the relationships that exist between gender construction and intimate relationships through the analysis of the Gamson and Modigliani framing models. This research uses descriptive qualitative method, where the data presented, are not in the form of numbers and more emphasis on meaning rather than generalization. Data collection techniques used are using documentation techniques and unobtrusive observation techniques, where this technique is a technique used to examine texts, and audio-visual recordings. This research was conducted during the 2019 October to January 2020. The research object is the novel "Friendzone: Lempar Kode Sembunyi Hati" by Alnira, that released on February 2018 with 300 pages. Then the object is dissected using the Gamson and Modigliani Framing analysis model to see how the expression of feelings constructed by gender in Dira and Ransi characters on the novel. The results of this research are, gender can affect the expression of a man and woman in expressing their feelings, where men express their feelings through gestures and non-verbal actions, while women need a recognition of the status of the relationship through their verbal. In addition, gender construction will influence the success of intimate relationships between men and women, if misunderstandings that occur due to differences in conversation patterns can be resolved.
\end{abstract}

Keywords: gender construction; framing; novel; intimate relationship.

\section{PENDAHULUAN}

Proses komunikasi selalu terjadi setiap saat dalam kehidupan sosial seorang manusia, tak hanya untuk melakukan pertukaran gagasan antar individunya, melainkan juga sebuah proses yang terjadi dalam rangka menunjukkan eksistensi diri seseorang, dalam komunikasi sendiri, banyak diketahui berbagai jenis komunikasi yang dilakukan untuk menyamakan presepsi atau menyepakati makna mengenai suatu gagasan yang dimiliki kepada individu maupun khalayak luas, salah satu jenis dalam komunikasi adalah komunikasi verbal. Komunikasi verbal merupakan segala jenis komunikasi yang berhubungan 
dengan bahasa yang bukan sebuah simbol, dalam komunikasi verbal banyak sekali hal-hal yang dapat memengaruhi konstruksi makna yang ingin disampaikan, seperti latar belakang budaya, tempat asal, latar belakang pendidikan dan juga jenis kelamin.

Menurut Mulyana (Mulyana, 2014: 315) Komunikasi Verbal, terdapat perbedaan cara berkomunikasi yang dilakukan oleh pria dan wanita. Wanita cenderung menggunakan pertanyaan sebagai strategi memelihara pembicaraan, serta memulai giliran berbicara dengan secara langsung mengakui andil pembicaraan sebelumnya serta lebih sering membuat asumsi yang diyakininya adalah suatu kebenaran, pria cenderung tidak mengakui apa yang dikatakan sebelumnya, melainkan menyatakan pendapatnya.

Pola komunikasi yang terjadi antara pria dan wanita sering disebut sebagai komunikasi gender, Pola komunikasi yang terjadi antara pria dan wanita menunjukkan sebuah identitas diri. Maka dari itu, pria dan wanita memiliki caranya sendiri dalam mengekspresikan dirinya sendiri, baik mengekspresikan diri dalam hal yang berhubungan dengan emosional maupun interaksinya. Dalam hal ini, peneliti tertarik untuk meneliti pengekspresian pria dan wanita yang dapat memengaruhi keintiman hubungannya (Intimate Relationship).

Jika dilihat dalam kehidupan seharihari, seringkali kita temui perbedaan cara berkomunikasi pria dan wanita yang dapat memengaruhi relasi keintiman dalam hubungannya. Permasalahanpermasalahan tersebut antara lain seperti pertengkaran dalam hubungan, kesalahpahaman dalam menyatakan gagasan, perbedaan cara mengekspresikan perasaan, hingga terjadinya perceraian dalam hubungan pernikahan. Salah satu faktor penting yang menyebabkan adanya permasalahan tersebut adalah makna-makna komunikasi yang tidak sampai dengan baik karena adanya perbedaan pola komunikasi antara pria dan wanita.

Novel merupakan cara penulis dalam menyampaikan gagasan/ ide pemikirannya. Lewat karya sastra, penulis banyak menceritakan sesuatu yang dekat dengan kehidupan sehari-hari sehingga mudah untuk membuat pembacanya terbawa suasana yang digambarkan penulis. Novel juga dapat berperan sebagai media untuk mengkonstruksi realitas yang ada di masyarakat. Seperti, kebudayaan di sekitar mereka, pribadi-pribadi yang ada di sekitar mereka, dan persepsi-persepsi yang ada di masyarakat. Novel dengan genre romantis yang banyak menceritakan tentang hubungan percintaan antara pria dan wanita menjadi sebuah media untuk menyampaikan bagaimana pola komunikasi antara pria dan wanita yang bahkan di dalamnya pun dapat ditemui permasalahanpermasalahan dalam relasi intim yang juga sering kita temui dalam kehidupan sehari-hari seperti yang telah disebutkan sebelumnya. Oleh karena itu, novel juga dapat dikaji sebagai obyek penelitian untuk melihat relasi keintiman antara pria dan wanita yang dapat dilihat melalui konteks komunikasi dalam dialog atau narasi dalam novel bergenre romantis tersebut.

Dilihat dari perspektif komunikasi, di dalam novel banyak terkandung maknamakna komunikasi yang tersembunyi dalam narasi dan dialog yang dibuat oleh penulis novel. Novel dijadikan sebagai media massa yang dapat memengaruhi pembacanya baik dalam segi emosional maupun memengaruhi pembacanya dari segi gagasan. Jika penulis novel menggambarkan sebuah cerita yang sedih, 
pembacanya dapat ikut menangis, jika penulis menggambarkan sesuatu yang romantis, pembacanya juga dapat ikut tersipu. Bahkan novel juga dapat dijadikan sebagai media penyampai informasi. Penelitian ini lebih berfokus bagaimana konstruksi gender dapat memengaruhi seseorang dalam mengungkapkan/mengekspresikan

perasaan cintanya sehingga terdapat relasi dalam membangun sebuah Intimate Relationship serta untuk membongkar makna yang dikomunikasikan antara pria dan wanita berdasarkan konstruksi gender sehingga permasalahan yang terjadi karena kesalahpahaman dalam komunikasi dapat diselesaikan tanpa harus terjadi sebuah perpisahan dalam suatu hubungan antara pria dan wanita. Yang dijadikan obyek dalam penelitian ini adalah Novel berjudul Friendzone: Lempar Kode Sembunyi Hati Karya Alnira.

Cerita dalam novel ini dimulai oleh Andira Ramadhani, seorang Financial Adviser dan keempat sahabatnya yaitu Maya, Angga, Ransi dan Wisnu yang mulai menjalin persahabatan mereka setelah acara reuni dengan teman SMP nya. Setelah acara reuni tersebut, mereka yang semakin dekat memutuskan untuk membuat sebuah perjanjian dengan tujuan agar tidak merusak persabatan yang terjalin di antara mereka, yaitu untuk tidak jatuh cinta satu sama lainnya namun, menepati perjanjian itu tidaklah mudah, perjanjian itu hanyalah tinggal perjanjian karena beberapa tahun setelah perjanjian itu dibuat, tiga dari mereka melanggar perjanjian tersebut. Salah satunya adalah Dira yang mencintai Ransi. Diantara keempat sahabatnya, Dira memang lebih dekat dengan Ransi. Ransi yang selalu ada untuk Dira, Ransi yang selalu bercerita kepada Dira, dan Ransi yang terkadang menyelipkan kodekode misterius yang tak pernah dimengerti Dira. Kedekatan tersebut jugalah yang membuat Dira lama kelamaan merasa nyaman dan akhirnya menaruh perasaannya pada Ransi, namun sayangnya Ransi yang terlalu cuek dan rasional membuat Dira sulit untuk menebak bagaimana perasaan yang dmiliki Ransi untuk Dira. Dira terkadang merasa bahwa Ransi juga memiliki perasaan yang sama karena tingkah Ransi yang seringkali berlaku manis kepada Dira, namun terkadang Dira ragu tentang perasaan Ransi karena Ransi yang tak pernah mengatakan secara gamblang perasaannya.Berbagai kesalahpahaman juga terjadi mengiringi perjalanan Dira dan Ransi, hingga nantinya Dira dan Ransi akan menemukan suatu titik balik hubungan mereka.

Bagaimana penulis menceritakan tentang kontrasnya sikap Dira, seorang perempuan yang membutuhkan penjelasan secara gamblang dan Ransi, seorang laki-laki yang sedikit berbicara namun banyak bertindak inilah yang menggambarkan bagaimana perbedaan pola pikir, serta pola berkomunikasi dan berbahasa antara pria dan wanita dalam mengekspresikan perasaannya dan hal tersebut berimbas pada keintiman hubungan mereka. Adanya permasalahan dalam relasi intim yang juga dapat dikaji melalui novel membuat peneliti tertarik dan berfokus untuk menganalisis konstruksi gender dalam relasi Intimate Relationship yang terdapat dalam novel Friendzone karya Alnira tersebut.

\section{METODE}

Penelitian ini menggunakan pendekatan Kualitatif, adapun jenis penelitian ini adalah deskriptif kualitatif, di mana data yang disajikan tidak berupa angka-angka. Sugiyono (Sugiyono, 2011 : 9) mengemukakan bahwa penelitian kualitatif adalah penelitian yang 
berlandaskan pada filsafat dan digunakan untuk meneliti objek ilmiah, di mana peneliti merupakan intrumen kunci, dan hasil dari penelitian kualitatif lebih menekankan pada makna dibanding generalisasi. Peneliti juga menggunakan metode Observasi unobtrusive. Observasi jenis ini dilakukan pada naskah, teks, tulisan, dan rekaman audio visual, materi budaya (objek fisik), jejak-jejak perilaku, arsip pekerjaan, pakaian atau benda lain di museum, isi dari buku-buku di perpustakaan, observasi sederhana, hardware techniques; kamera, video, dll, rekaman politik, dan demografi (Babbie, 1998: 308). Dalam penelitian ini yang termasuk data primer adalah narasi dan dialog dalam Novel "Friendzone: Lempar Kode Sembunyi Hati" karya Alnira yang mengandung Metaphor, Catchphrases, Exemplaars, Depiction, dan Visual Image serta Roots, Appeal to Principle, dan Concequence. Sedangkan data sekundernya berupa informasi yang didapat dari literatur, jurnal, internet dan sumber-sumber lainnya yang mendukung dan berhubungan dengan topik penelitian.

Analisis data yang digunakan adalah Analisis Framing model Gamson dan Modigliani, yang akan meneliti dan membongkar makna yang terbentuk tergantung pada gagasan sentral yang didukung oleh perangkat-perangkat wacana seperti: kata, kalimat, dan bantuan visual gambar atau grafis. Untuk kemudian dibagi lagi menjadi elemenelemen yang mengarah pada gagasan sentral tersebut. Peneliti menganalisis pengekspresian perasaan tokoh yang dikonstrusi oleh gender dan perkembangannya dalam relasi intim yang terdapat dalam novel Friendzone: Lempar Kode Sembunyi Hati karya Alnira dengan cara menunjukkan elemenelemen yang mengkonstruksi makna melalui beberapa dialog dan narasi yang dituliskan oleh Pengarang yang di dalamnya terdapat Metaphor, Catchphrases, Exemplaars, Depiction, Visual Image, Roots, Appeal to Principle, dan Concequence.

Data yang diperoleh peneliti dari hasil framing novel "Friendzone: Lempar Kode Sembunyi Hati", kemudian disajikan dalam bentuk uraian dan tabel setelah peneliti melakukan teknik pengolahan data dengan membingkai narasi dan dialog yang menunjukan makna dalam pengekspresian perasaan dan berpengaruh pada relasi Intimate Relationship yang terkonstruksi oleh gender, dilihat dari segi komunikasi gender, komunikasi interpersonal, konstruksi realitasnya, serta penokohan. Dalam penyajian data, peneliti harus dapat menyajikan secara sistematis sehingga data yang diperoleh dapat menjelaskan dan menjawab permasalahan yang diteliti.

\section{HASIL DAN PEMBAHASAN}

Hasil yang ditemukan dari penelitian ini menunjukkan bahwa terdapat konstruksi gender yang dibangun Alnira selaku penulis novel pada tokoh Dira dan Ransi, di mana konstruksi gender tersebut dipengaruhi oleh latar belakang yang dimiliki oleh tokoh-tokoh tersebut. Dalam perkembangan hubungan yang mereka alami terdapat berbagai kesalahpahaman, karena pola percakapan antara pria dan wanita yang pada dasarnya berbeda seperti yang dikatakan oleh Tannen bahwa pria dan wanita memiliki perbedaan yang didasari oleh perbedaan budaya yang menyebabkan munculnya kesalahpahaman pria dan wanita untuk melakukan percakapan, berdasarkan perbedaan budaya yang membentuk pria dan wanita. Pengkonstruksian gender tersebut dapat diketahui melalui analisis framing model Gamson dan Modigliani yang disusun 
oleh elemen inti (idea element) dan perangkat pembingkai (framing devices). Elemen inti yang ditemukan membentuk konstruksi gender yang berdasarkan pada konstruksi realitas atas latar belakang Dira dan Ransi. Realitas Dira terbentuk karena adanya relasi Dira dengan ibu kandungnya, orang tua angkat, sahabatsahabat Dira dan relasinya dengan Ransi. Relasi-relasi nya ini mengkonstruksi Dira sebagai perempuan yang mandiri, teguh pendirian serta berhati-hati dalam pergaulannya. Dira yang merupakan anak di luar nikah memutuskan untuk menjaga jarak dan lebih berhati-hati dalam memilih pasangan, karena ia tidak ingin apa yang terjadi pada ibunya akan terjadi kembali kepada dirinya. Lingkungan Dira yang notabene memiliki banyak sahabat lelaki dibandingkan perempuan, membuat Dira dijaga layaknya Adik oleh sahabat-sahabat Dira yaitu Angga, Wisnu, Ransi dan juga Maya. Penjagaan ini menyebabkan Dira banyak diberikan nasihat dalam memilih pasangan. Sedangkan relasi yang terbentuk antara Dira dan ransi merupakan relasi yang lebih intim di mana terdapat sebuah ikatan emosional antara keduanya. Hal itu menyebabkan adanya beberapa perubahan dalam sikap Dira untuk menghadapi ransi, seperti lebih terbukanya Dira pada Ransi, Dira yang merupakan perempuan mandiri, dapat menjadi seseorang yang lebih ketergantungan pada kehadiran Ransi, serta Dira lebih menaruh perhatian pada Ransi.

Konstruksi realitas Ransi juga terbentuk karena latar belakang Ransi yang terhubung pada relasi Ransi dengan keluarganya, serta realitas Ransi dengan Dira. Latar belakang Ransi yang merupakan anak pertama serta seorang putra dari orangtua yang memiliki latar belakang pendidikan membuat Ransi menjadi seorang pria yang bertanggung jawab, disiplin, pendiam serta tertutup, hal ini dikarenakan ransi harus menjadi panutan bagi adik-adiknya serta muridmurid yang diajarnya. Cita-cita Ransi sebagai seorang guru pun menjadi sebuah beban tersendiri dikarenakan Ayah ransi yang juga bekerja di bidang pendidikan, oleh karena hal tersebut Ransi berusaha untuk membuktikan eksistensi nya agar diakui sebagai seorang guru yang dapat berkembang berdasarkan kerja kerasnya sendiri, tanpa harus dibantu oleh kedudukan yang dimiliki ayahnya. Relasi yang terbentuk antara Ransi dengan Dira pun merupakan sebuah relasi intim yang terikat oleh emosional, hal ini dapat dilihat dari bagaimana sikap rasi yang tampak berbeda dalam menyikapi Dira. Ransi dalam menghadapi Dira tampak lebih ekspresif, serta lebih terbuka dan perhatian, meskipun hal tersebut, lebih banyak ditunjukan melalui non-verbal dibandingkan verbalnya.

Komunikasi gender yang terjalin antara Dira dan Ransi menggambarkan adanya perbedaan pola percakapan antara pria dan wanita di mana pria lebih banyak menganggap bahwa Komunikasi yang terjalin adalah sesuatu yang dianggap sebagai sumber informasi serta Pelayanan status Sedangkan bagi wanita pola percakapan merupakan sesuatu untuk menjalin koneksi. berdasarkan hasil penelitian, pola komunikasi yang digunakan Ransi kepada Mega yang merupakan teman perempuannya adalah sesuatu yang berlandaskan sopan santun tanpa melibatkan emosional, sedangkan bagi Dira, jika melihat dari perspektif wanita sikap yang ditunjukkan Ransi tersebut dapat menimbulkan salah paham pada Mega. Hal ini sejalan dengan teori yang dikemukakan oleh Tannen bahwa, percakapan pria berorientasi pada pesan, yaitu berdasarkan pada komunikasi informasi. Bagi wanita, percakapan jauh lebih penting untuk membangun 
Paradigma: Jurnal Filsafat, Sains, Teknologi, dan Sosial Budaya

Volume 26, Nomor.1, April 2020

hubungan dan memperkuat hubungan sosial. Hal ini disebabkan karena adanya perbedaan gaya percakapan yang terjadi sehingga dapat menimbulkan suatu kesalahpahaman dan dapat memengaruhi komunikasi itu sendiri.

Relasi yang terjadi antara Dira dan Ransi pun tak lepas dari adanya komunikasi Interpersonal yang terjalin antara kedua tokoh tersebut. Komunikasi Antarpribadi/interpersonal sendiri, berperan penting hingga kapanpun, dan pada nyatanya komunikasi antarpribadi membuat orang lebih akrab dari sebelumnya (Mulyana, 2014: 81). Itulah

alasan mengapa Komunikasi antarpribadi akan sangat berpengaruh dalam terjalinnya sebuah hubungan. Berdasarkan hasil penelitian, Alnira menggambarkan relasi yang terjadi antara Dira dan Ransi lebih dekat dibandingkan dengan sahabat-sahabat mereka yang lainnya, dikarenakan adanya rasa terikat karena Dira dan Ransi saling memahami, serta dibantu dengan adanya rasa tertarik yang dimiliki oleh tokoh Dira dan Ransi.

Jika dilihat melaluit Perangkat Pembingkaian (Framing Devices), maka dapat ditemukan hal-hal berikut:

Tabel. 1. Hasil Penelitian Menggunakan Model Gamson dan Modigliani

Frame

(Konstruksi Gender dalam Novel Friendzone: Lempar Kode Sembunyi Hati

Perangkat Framing

(Framing Device)

- "Hahaha, kamu tahu nggak. Kalau diibaratkan, kamu itu sungai dan aku lautnya."

"Maksudnya?"

Metaphors "Kamu tahu nggak? Air sungai itu bermuaranya ke mana?"

"Laut?"

"Nah, itu tau. Jadi mau ke mana pun alirannya, air sungai itu tetap bermuara ke laut. Cuma itu aja yang perlu kamu inget,” katanya sambil mengusap kepalaku. (Dalam bab 20: 198)

- "Kamu tahu, Ran, aku dulu juga pernah susah. Kamu tahu kan kalau aku dulu harus berhenti kuliah karena ayahku meninggal? Harus kerja untuk cari biaya

Catchphrases kuliah. Aku bukan anak orang kaya yang manja, kita bisa sama-sama cari uang, kan?"

“Justru kamu pernah hidup susah jadinya aku nggak mau ngajak kamu susah lagi." (Dalam bab 23: 231)

- "Kamu yakin suka aku dari tujuh tahun lalu, tapi kamu jadian sama orang

Exemplaars lain, Dir, " katanya sambil menatap tajam padaku.

"Tapi itu kan karena kamu nggak ada kepastian! Wajar kalau aku berusaha melupakan kamu." (Dalam bab 28: 278)

- "Dir, rasa itu bisa datang dengan sendirinya. Kamu jangan nutup mata.

Depiction Ransi nggak ada kepastian. Si Zaki kayaknya kalau kamu pancing dikit juga udah siap ngelamar. Kalau sama Zaki kamu nggak harus nunggu dua tahun, Dir. Dia udah punya rumah, mobil, kerjaan. Dia juga mapan. Apalagi yang kamu cari?" (Dalam bab 22: 214)

Perangkat Penalaran

(Reasoning Device)

Roots (Analisis • "Mega itu nggak masuk hitungan. Asal kamu tahu, dia itu jadi tumbal aja, ngerti kamu? Dan Fia? Dia itu cuma rekan kerja aku." 
Paradigma: Jurnal Filsafat, Sains, Teknologi, dan Sosial Budaya

Volume 26, Nomor.1, April 2020

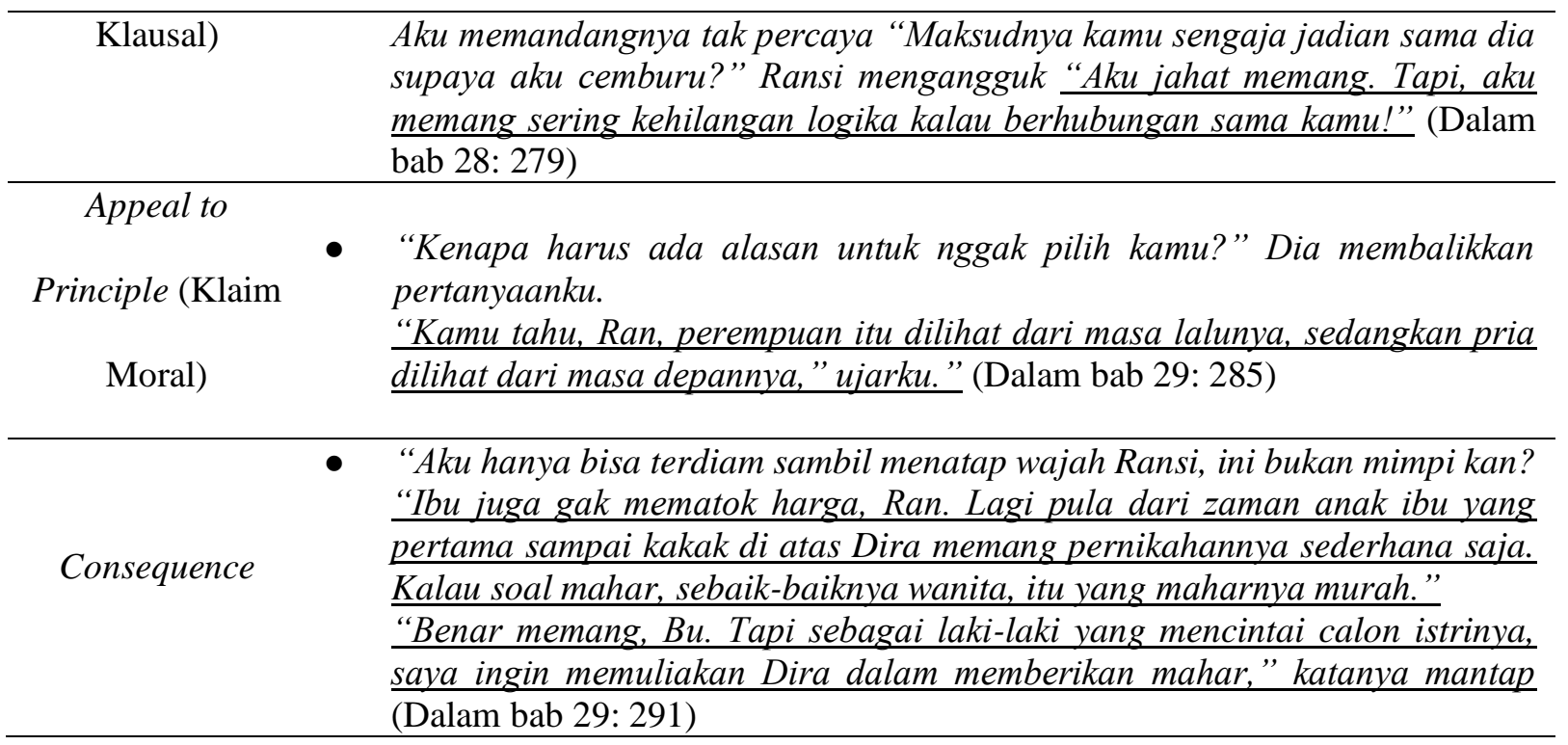

Perangkat Pembingkaian (Framing Devices)

\section{a. Metaphors:}

Pada elemen ini dijelaskan bahwa, Ransi menunjukkan perasannya menggunakan kalimat pengandaian, ia mengibaratkan dirinya sebagai laut dan Dira adalah sungainya. Sehingga, ke mana pun Dira pergi, pada akhirnya ia akan tetap kembali pada Ransi. Ketika Dira meminta penjelasan akan perasaan Ransi padanya, Ransi mengandaikan perasaannya sebagai sebuah kunci, Ransi memberikan kunci tersebut hanya pada Dira yang artinya ia hanya akan membiarkan Dira sebagai satu-satunya orang yang memiliki perasaan cinta Ransi. Pengandaian yang ditunjukkan oleh Ransi, menggambarkan sikap Ransi yang penuh teka-teki dan misterius. Hal ini pun menjelaskan bahwa seorang seorang pria menganggap bahwa dengan sikap/gestur yang ia tunjukkan akan menggambarkan perasaan yang dimiliki dengan jelas, namun ketika wanita meminta dengan jelas mengenai penegasan status secara verbal, maka pria akan dengan gamblang menjelaskan perasaannya melalui verbalnya.

b. Catchphrases:

Elemen ini menjelaskan bahwa jika seorang pria beranni berkomitmen, maka ia harus berani mempertanggung jawabkan keputusan yang telah ia ambil, dalam hal ini juga dijelaskan ego seorang pria mengenai masalah finansial dalam sebuah keluarga, di mana sebagai kepala keluarga pria bertanggung jawab untuk menanggung seluruh biaya keluarganya, sementara wanita sebagai istri adalah pihak yang harus dimanjakan oleh seorang pria dan wanita haruslah diperlakukan dengan nyaman dan pantas.

c. Exemplaars:

Elemen ini menjelaskan bahwa wanita membutuhkan sebuah kepastian dalam sebuah hubungan, apabila kepastian dalam sebuah hubungan tersebut tidak didapatkan, maka seorang wanita akan membuat berbagai opsi untuk mencari kepastian tersebut. Seperti yang dikatakan oleh Lord Byron (dalam DeVito, 2015: 218) bahwa bagi seorang wanita cinta dan hubungan adalah 
keseluruhan eksistensinya. Wanita digambarkan emosional dan sangat mengagungkan perasaan cinta, sedangkan laki-laki adalah individu yang logis dan membedaka antara kehidupan dan percintaan.

\section{d. Depictions:}

Pada elemen ini dijelaskan bahwa terdapat sebuah penilaian yang terbentuk dalam lingkungan yang dikenakan pada kaum pria mengenai kesiapan untuk bertanggung jawab dan kesiapan memulai sebuah pernikahan. Seorang pria dengan kondisi finansial tidak stabil dianggap belum siap untuk memulai rumah tangga dan bertanggung jawab pada keluarganya. Sedangkan wanita seringkali dituntut untuk mencari pendamping hidup yang sudah mapan dibandingkan pendamping yang memang dicintai.

\section{Perangkat Penalaran (Reasoning Devices)}

\section{a. Roots (Analisis Klausal)}

Elemen ini menunjukkan bahwa perbedaan dalam percakapan antara pria dan wanita akan menimbulkan sebuah kesalahpahaman. Kesalahpahaman ini selain karena perbedaan latar belakang, juga disebabkan oleh ego yang dimiliki oleh pria dan wanita, di mana dalam hubungan baik pria maupun wanita merasa bahwa apa yang dilakukannya untuk mengekpresikan perasaannya adalah cara yang benar, tanpa mengetahui bahwa hal tersebut akan memunculkan asumsi yang tidak dilandasi fakta.

b. Appeal to Principle (Klaim Moral) Elemen ini menjelaskan bahwa dalam lingkungan sekitar, wanita akan dinilai berdasarkan masa lalu yang dimilikinya, sedangkan pria akan dinilai berdasarkan masa depannya. Pandangan ini merupakan klaim moral yang telah berkembang dalam kehidupan masyarakat berbudaya. Masa lalu dianggap dapat memengaruhi kualitas seorang perempuan.

c. Consequences

Komunikasi yang dilakukan dalam hubungan antara pria dan wanita merupakan sebuah hal krusial, apabila komunikasi yang terjalin tidak berjalan dengan efektif, maka akan menimbulkan kesalahpahaman, karena adanya perbedaan dalam percakapan yang dilandasi oleh konstruksi gender yang dimiliki pria dan wanita. Ketika pria dan wanita memutuskan untuk menurunkan ego masing-masing, maka hubungan yang terjalin akan berujung pada sebuah komitmen yang terjalin dengan baik.

Dari dua tokoh tersebut, dapat dipahami bahwa konstruksi akan gender diberikan oleh lingkungan kepada seseorang yang akan membentuk kepribadian orang tersebut, sehingga munculah berbagai perbedaan yang didasari oleh perbedaan peran oleh pria dan wanita dalam lingkungan, bahkan konstruksi gender memiliki relasi yang kuat dengan Intimate relationship yang terjalin antara pria dan wanita. Kuatnya pengaruh gender ini bahkan juga dibuktikan melalui identifikasi level individu yang berdasarkan pada wawancara dengan pembaca novel Friendzone: Lempar Kode Sembunyi Hati, di mana novel ini memiliki kaitan dengan realitas yang ada. Pada kenyataannya, hal-hal seperti kesalahpahaman dalam pengungkapan perasaan sering terjadi, lantaran munculnya asumsi-asumsi tanpa penjelasan dari kedua belah pihak. Wanita seringkali merasa enggan untuk menyatakan perasaannya terlebih dahulu karena merasa bahwa kodrat seorang wanita adalah untuk dijekar dan bukan mengejar. Wanita juga menganggap bahwa pengakuan akan status yang jelas secara verbal merupakan sebuah hal 
penting dalam berjalannya sebuah hubungan. Sedangkan pria, menganggap bahwa perasaan yang serius, dapat ditunjukkan melalui tingkah laku dan gestur kepada orang yang dicintai, bagi pria gestur yang dilakukan kepada wanita yang dicintai akan sangat menampakkan dengan jelas perasaan yang mereka miliki, sedangkan wanita menganggap hal tersebut hanya akan memunculkan spekulasi yang ambigu. Ketika pria dan wanita memutuskan untuk menurunkan ego masing-masing dan mulai menjelaskan mengenai suatu hal dari perspektif keduanya, maka permasalahan komunikasi yang dilandasi oleh peran gender pria dan wanita akan dapat diselesaikan.

Novel Friendzone: Lempar Kode Sembunyi Hati karya Alnira ini, juga menggambarkan perkembangan intimate relationship yang terjalin antara kedua tokoh utamanya. Pada awalnya hubungan yang mereka miliki adalah jenis hubungan liking, yaitu jenis hubungan yang biasa terjadi pada hubungan pertemanan, Kemudian hubungan tersebut berkembang menjadi hubunga Romantic Love, yang terjalin ketika mereka menjadi sepasang kekasih Tahap terakhir adalah Consummate Love, ketika Dira dan Ransi akhirnya menikah.

Fase hubungan yang terjadi antara tokoh Dira dan Ransi, jika dikaji dengan teori perkembangan hubungan Knapp, maka, tahap inisiasi yang terbentuk adalah saat reuni, ketika itu terjadi sebuah kontak antara Dira dan Ransi setelah lama tidak bertemu.

"Aku Akbar" Jawabnya.

"Kamu Ransi, kok Akbar, sih?" Seingatku namanya Ransi, bukan Akbar (Bab 1: 5).

Fase berikutnya adalah Eksperimen, saat itu Dira mulai mencari tahu informasi tentang Ransi, seperti hari ulang tahun Ransi dan Dira membuatkan kue untuknya, karena hal itu pula Dira menyadari bahwa ia menyukai Ransi.

\begin{abstract}
Aku ingat sekali kapan kali pertama aku menyadari perasaan ini tidak lagi murni antara sahabat, tapi sudah berkembang menjadi cinta, saat ulang tahunnya yang ke dua puluh dua. Aku yang memang senang membuat kue, kali pertama membuat kue tar khusus untuknya. Saat dia mencicipi kue itu aku melihat binar bahagianya. (Bab 3: 21).
\end{abstract}

Kemudian tahap Intensifikasi, pada tahap ini terjadi perubahan sikap pada dua tokoh, seperti saat Ransi rela menjemput Dira yang pulang malam sendiri meskipun jaraknya jauh, serta bersikap lebih terbuka kepada Dira dibandingkan orang tuanya.

Akbar Ransi A: Kenapa?
Andira Ramadhani: Aku masih meeting
di kantor, mau pulang takut, naik motor
sendirian soalnya Akbar Ransi A: Ya udah tunggu. Aku Jemput. (Bab 3: 23).

"Kamu nggak coba jelasin sama mama kamu?" tanyaku.

"Aku belum berani ngomong, ini juga ngomongnya baru sama kamu."

"Kenapa ngomongnya sama aku?"

"Kamu kan sahabat aku, Dir."

Lagi-lagi kata itu yang keluar dari mulutnya.

"Ya kenapa aku? Kan ada yang lain?"

"Ya karena aku nyamannya cerita sama kamu” ujarnya. (Bab 6: 43).

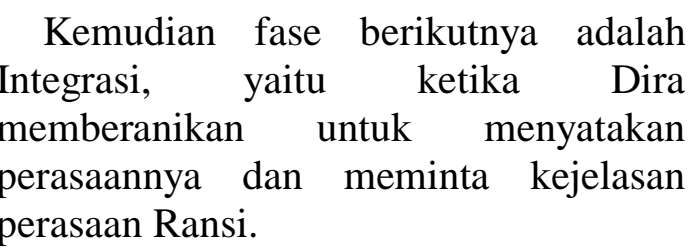

"Itu kunci aku kasih buat kamu. Memang nggak kasatmata, sama kaya perasaan 
Paradigma: Jurnal Filsafat, Sains, Teknologi, dan Sosial Budaya

Volume 26, Nomor.1, April 2020

aku ke kamu. Nggak bisa dipegang tapi bisa kamu rasa. Aku kasih kunci itu ke kamu, yang artinya kamu adalah satusatunya wanita yang punya akses untuk jadi istriku. Dan kunci itu gak ada duplikatnya," katanya sambil mencium tanganku yang sedang digenggamnya. (Bab 23: 234).

Fase terakhir yaitu Ikatan, di mana fase ini terjadi pada 29 dan Bab Epilog, Ransi menyatakan keseriusannya dengan Dira dan melamar Dira pada ibunya, kemudian pada bab Epilog telah dijelaskan bahwa Ransi dan Dira telah menikah.

"Iya, dulu rencananya memang seperti itu, Bu. Tapi setelah saya pikir ulang dan berunding dengan keluarga, sepertinya semakin cepat semakin baik. Tapi saya tidak bisa mengadakan pesta yang mewah. Namun, untuk mahar, Inshaallah saya bisa memuliakan Dira, Bu." (Bab 29: 291).

Mereka sudah menikah 7 bulan yang lalu. Pernikahan sederhana yang memang menjadi impian Dira. (Bab Epilog: 297)

\section{KESIMPULAN}

Novel Friendzone: Lempar Kode Sembunyi Hati mengamini konsep konstruksi realitas yang didasari oleh latar belakang yang dimiliki dan relasi seseorang. Konstruksi gender yang terbentuk pada novel ini, memberikan pengaruh pada karakter dan sikap tokoh yang juga memengaruhi tokoh dalam menunjukkan perasaannya. Dalam hal ini, tokoh Ransi digambarkan menunjukkan perasaannya melalui tindakan yang mengandung makna intim seperti, mengelus rambut Dira, memberikan jaketnya untuk menutupi kaki Dira, memberikan akses gawainya pada Dira agar tak ada rahasia di antara mereka. Sementara tokoh Dira menunjukkan perasaannya melalui verbal seperti, bertanya langsung mengenai perasaan Ransi padanya dan meminta penegasan akan kejelasan hubungan Ransi dengan dirinya. Bentuk pengekspresian yang ditunjukkan oleh tokoh Dira dan Ransi memberikan pengaruh berupa berkembangnya intimate relationship yang terjalin antara tokoh Dira dan Ransi. Perkembangan hubungan Dira dan Ransi, setelah dianalisis dengan segitiga cinta Sternberg dapat diketahui bahwa hubungan Dira dan Ransi berkembang dari Liking, di mana hubungan ini dikategorikan saat Dira dan Ransi masih berteman. Romance, ketika Dira menyatakan perasaannya pada Ransi, dan Ransi menegaskan bahwa hubungan keduanya adalah sepasang kekasih dan Consummate love, ketika Ransi meminta izin pada ibu Dira untu menikahi Dira, dan keduanya menikah.

\section{DAFTAR PUSTAKA}

Alnira. 2018. Friendzone: Lempar Kode Sembunyi Hati. Jakarta : Grasindo

Babbie, Earl. 1998. The Practice of Social Research $8^{\text {th }}$ Edition. Belmot: Wodsworth Publishing Company

Berger, Peter L \& Thomas Luckmann. 1991. The Social Construction of Reality. England : Penguin Books

Eriyanto. 2012. Analisis Framing. Yogyakarta : LKiS

Knapp, Mark. L dan Anita L. Vangelisti. 2005. Interpersonal Communication and Human 
Paradigma: Jurnal Filsafat, Sains, Teknologi, dan Sosial Budaya

Volume 26, Nomor.1, April 2020

Relation $5^{\text {th }}$ Edition. Boston:

Allyn and Bacon.

Sugiyono, 2011. Metode Penelitian Kualitatif dan Kuantitatif dan R \&

Littlejohn, Stephen W \& Karen A Foss. 2009. Teori Komunikasi Edisi 9.

Jakarta : Salemba Humanika

D. Bandung : Alfabeta

Sternberg, R.J. 1986. Triangular Theory of Love. Psychological Review. 93(2): 119-135. Amerika Serikat: Yale Univrsity

Sebagai Pengantar Cetakan 18.

Bandung : PT. Remaja Rosdakarya

Tannen, Deborah. 1990. You Just Don't Understand: Woman and Men In

Nurgiyantoro, Burhan. 1998. Teori Pengkajian Fiksi. Yogyakarta : Conversation. New York : Ballantine Books

Gadjahmada University Press 